\title{
INDEPENDENT BUT NOT INDIFFERENT: PARTISAN BIAS IN MONETARY POLICY AT THE FED
}

\author{
William Roberts Clark* AND VinCENT AREl-Bundock
}

\begin{abstract}
Independent central banks are thought to be effective inflation hawks because they are run by technocrats with conservative monetary policy preferences. However, central bankers can only protect their independence by compromising with the elected officials who grant them their independence. Policy, therefore, is likely to be a weighted average of the preferences of the central bank and the government. Consequently, central bankers may be eager to help right-wing governments stay in power and oppose the election of left-wing governments. We show evidence from the United States that interest rates (a) decline as elections approach when Republicans control the White House, but rise when Democrats do; and (b) are sensitive to the inflation rate (output gap) when Democrats (Republicans) are in the White House. Thus, the Federal Reserve is a conditional inflation hawk. Since the Fed became operationally independent in 1951, the Republicans have exhibited a decided electoral advantage in presidential politics.
\end{abstract}

The Federal Reserve System of the United States has long been considered one of the most independent central banks in the world. Independent central banks are thought to be effective inflation hawks because they are run by technocrats with more conservative monetary policy preferences than the median voter (Rogoff, 1985). In this article, we argue that if central bankers derive inflation fighting powers from strongly held, extreme preferences, then these preferences over policy may translate into preferences over who governs. Specifically, if the Fed has preferences to the right of Republicans, and if monetary policy is driven in part by the preferences of the President, then the Fed should prefer to see Republican presidents get elected. We analyze data on over half a century of monetary policy in the United States, and find that the Fed acts in ways that promote the (re)election of Republican presidential candidates. The Fed's main policy tool, the Federal Funds Rate (FFR), declines as elections approach when Republicans control the White House, but rises before elections when the sitting President is a Democrat. In addition, we find that the FFR responds to the inflation rate only when Democrats are in the White House, but responds to the size of the output gap in preelectoral periods only when the Republicans are in the White House. In summary, the Federal Reserve is a conditional inflation hawk-it cares about inflation, but only when the President is a Democrat.

In a recent book, Bartels (2010) points to the "Republicans' surprising success in concentrating income growth in election years" which, in turn, helps explain why "Republican presidential candidates have fared so well over the past-half century." Our findings suggest that there are systematic differences in Fed behavior under Republican and Democratic presidents since the Fed became operationally independent in the middle of the twentieth century. These differences are most acute in preelectoral periods and, so, could plausibly affect electoral outcomes. Consequently, if

\footnotetext{
*Corresponding author: William Roberts, University of Michigan, 505 S State Street, 5700 Haven Hall, Ann Arbor, MI 48109-1045, USA. E-mail: wrclark@umich.edu
} 
the Fed is independent, but not indifferent, it could explain the Republican's success in concentrating income growth in election years.

Our argument introduces a small but consequential change in the traditional approach to the politics of monetary policy. Positive political economy models have typically replaced benevolent social planners with survival or vote-maximizing politicians. These politicians may have policy goals, but they must weigh these goals against the fact that retaining office is often a necessary condition for them to even achieve their objectives.

However, the positive political economy of monetary policy represents a partial exception to this trend. Analyses of the time inconsistency problem in monetary policy, for example, retain benevolent social planners to demonstrate the robustness of the problem: discretionary policy leads to higher than optimal inflation rates even if we are fortunate enough to have an economy run by benevolent social planners (Barro and Gordon, 1983; Kydland and Prescott, 1977). Elected politicians are thought to be particularly sensitive to the political pressures that ensue when output falls below the natural rate. They are, therefore, keen to trade increased inflation for output gains. This generates a time inconsistency problem - if politicians could commit to a low inflation rule, they would be able to produce an outcome closer to the social optimum, but short-term political pressures, perhaps induced by the electoral calendar, make such commitments incredible.

One solution (Rogoff, 1985) is to appoint a central banker whose preferences over inflation are sufficiently hawkish to produce, somewhat unwittingly, a socially desirable outcome despite falling victim to the time inconsistency problem. Another (Walsh, 1995) is to write a contract between the political principal and the central banker that ties the banker's compensation to its ability to meet predetermined policy goals. In the Rogoff model, elected officials who delegate to a conservative central bankers are essentially strategic benevolent social planners. Like Odysseus, they tie themselves to the mast and resign their fates to slaves with wax in their ears to accomplish what they could not achieve on their own - the optimization of a social welfare function. In the Walsh model, elected politicians sign a contract with the central banker that threatens to punish the banker if he fails to implement the socially optimal low inflation policy. Curiously, while the politician cannot behave as a benevolent social planner because of the time inconsistency problem, it is assumed that he will punish any central banker who fails to do so.

Canonical models of central bank independence, then, take one step forward and one step back. They treat politicians as electorally minded strategic actors capable of designing institutions that trick central bankers into producing policies preferred by the median voter. However, they assume that central bankers are apartisan technocrats who optimize within the constraints created by their political principals without considering how the choices they make today can shape the political environment tomorrow.

In this article, we consider what happens when the positive political economy approach is applied more fully to the political economy of central bank independence. What if both the elected principal and the central banker act like fully strategic actors? Our answer is that strategic, conservative central bankers should behave as conditional inflation hawks because doing so can result in the (re)election of political principals that more closely share their policy preferences. The idea that independent central bankers would intervene in such a partisan fashion is largely absent from the 
literature. Two important exceptions that presaged our argument are Cusack (2001) and Galbraith et al. (2007).

We analyze data on half a century of Fed policy to evaluate our argument. We find that the Fed raises interest rates as elections approach when Democrats control the White House, but lowers interest rates as elections approach under Republican administrations. Furthermore, when Democrats control the White House, the Fed increases interest rates in response to increased inflationary expectations, especially as elections approach, but it is insensitive to the gap between actual and potential output. The pattern is reversed under Republicans: the Fed lowers interest rates in response to declining growth - especially as elections approach - but is insensitive to inflationary expectations. These results are consistent with the idea that the Fed prefers Republican presidents, and that it acts to help ensure their election and reelection. Evidence presented below suggests that the political independence of the Fed allows it to act effectively in light of its political preferences: Republicans were much more effective in gaining and keeping the White House in the half-century after the Fed became operationally independent than in the period preceding operational independence.

In the next section, we explain why the Fed prefers that the White House be controlled by Republicans, and we discuss why this should lead it to act like a conditional inflation hawk. In section 2, we present evidence that the FFR is tied to the electoral calendar and that this link is different when Republicans control the White House than when Democrats do. We also present evidence that the Fed's reaction to inflation and the output gap depends on both the election calendar and the partisan orientation of the White House. We also explore the robustness of these results and compare them to the expectations of two rival approaches to the partisan control of monetary policy - the "rational partisan model" of Alesina and Rosenthal (1995), and the notion that monetary policy is driven the partisan orientation of the president that first appointed the sitting Fed chairman (Abrams and Iossifov, 2006). Section 3 summarizes our results and describes changes in the presidential electoral fortunes of the two parties during the (near) century since the creation of the Fed.

\section{THEORY: WHY WE EXPECT THE FED TO BE A CONDITIONAL INFLATION HAWK}

We argue that the Fed manipulates monetary policy in a partisan fashion. In this section, we articulate two steps of our argument. First, we explain why the Fed cares which party rules. Second, we show why this leads the Fed to respond to electoral and macroeconomic pressures in a manner that is conditioned by the party of the president.

\subsection{If Parties have Monetary Preferences, Conservative Central Bankers have Partisan Preferences}

The standard partisan model of monetary policy assumes that political parties represent constituencies with distinct preferences over inflation and unemployment (Hibbs 1977). One way to think of this is that net debtors are less concerned with inflation than net creditors and, so, place greater weight on achieving their output goals than their inflation goal. Even if both actors had the same output goal, the amount of inflation they would be willing to tolerate to accomplish that goal would differ. For example, imagine citizen $i$ 's policy preferences were given by the loss function: 


$$
L_{i}=\alpha\left(\pi-\pi^{*}\right)^{2}+(1-\alpha)\left(y-y^{*}\right)^{2},
$$

where $y$ is output, $y^{*}$ is $i$ 's output target (perhaps potential GDP), $\pi$ is inflation and $\pi^{*}$ is $i$ 's inflation target. Assume, without loss of generality, that all citizens in society share target rates for output and inflation (perhaps potential GDP and zero inflation). Individuals would still differ in their assessment of outcomes if they placed different weights on hitting these targets. Holding inflation constant, actors can be arrayed along a unit interval from $\alpha=0$ (output junkies) to $\alpha=1$ (inflation hawks). The partisan model of monetary policy assumes that left-wing parties represent the interests of voters with lower incomes who care more about output than inflation, placing them on the lower end of this unit interval. Right-wing parties are thought to represent high income individuals who care more about inflation than output, placing them on the upper end of this unit interval. The desire to represent the interests of voters in their constituencies induces ideal points for left and right-wing parties as pictured in Figure 1.

The Rogoff model of central bank independence maintains that the time inconsistency problem in monetary policy can be mitigated if politicians delegate policy to a central banker who is even more inflation averse than right-wing politicians. Thus, if central bank independence works the way Rogoff suggests, independent central bankers will have alpha's that place them to the right of right-wing parties as in Figure 1.

There are reasons to believe, however, that even independent central bankers will not be able to implement their ideal point. McCubbins and Schwartz (1984) argue that executive agencies granted with autonomy need to be mindful of the fact that the legislature that grants that independence can also take it away. Berger and Schneider (2000) show that the Bundesbank's policies moved in parallel with changes in the composition of the Bundestag. Keefer and Stasavage (2003) argue that a change in the composition of government is likely to lead to a change in the reversion point - the policy that the government would implement in the absence of independence. A rational central banker will seek to deter the government's abrogation of the agreement that led to his or her independence. Therefore, the banker should adopt a policy that is as close to its ideal point as possible, subject to the constraint that the political coalition needed to abrogate independence needs to be at least indifferent between the policy adopted by an independent central bank and the policy that would prevail in the absence of independence. The exact position adopted by an independent central banker will, therefore, be influenced by the political institutions that dictate what is necessary to change the status quo - including executive-legislative relations, the presence of a second house, super majority requirements, and whether the government is a coalition or single party government. However, in general, if the central banker's ideal point is to the right of the right-most party, the best it can do in the short run is move to the left when the left-wing party comes to power and to the right when a right-wing party comes to power. At the very least, we can expect policy to be somewhere in the interval between $R$ and $C B$ when there is a right-wing government in power and $L$ and $C B$ when there is a left-wing government in power (see Figure 1). If central banks

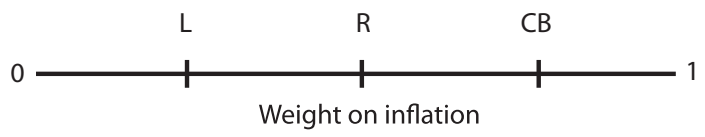

Figure 1. Spatial relationship between central bankers and parties. 
are (at most) partially independent, then we can think of equilibrium policy as being some convex combination (determined by the degree of independence) of the ideal points of the government and the central bank (Franzese, 1999). For all the reasons just stated, it is difficult to predict exactly where the optimal short run policy is for the central banker. Nevertheless, we can expect policy to be somewhere between the government's ideal point and the bank's ideal point and this location should be closer to the central bank's ideal point when right-wing governments are in power.

\subsection{Central Bankers with Partisan Preferences have Incentives to Influence Elections}

So far, our discussion suggests that we ought to observe fluctuations in interest rates in the United States which are consistent with the traditional partisan model. The Fed should guard its independence by accommodating left-wing policies as the political center of gravity moves to the left, and it is free to adopt a policy closer to its ideal point as the center of gravity moves to the right. An alternative model, the political business cycle model, presumes that politicians are responding to an electorate that votes in a rationally retrospective fashion - they vote for incumbents when economic growth in the preelectoral period exceeds some critical level, but vote for the challenger otherwise (Lohmann, 2003). Clark and Hallerberg (2000) and Alpanda and Honig (2009) argue that central bank independence ought to inhibit politicians' ability to engage in this sort of opportunistic behavior, though Alpanda and Honig (2009) find more evidence for this constraining effect of central bank independence in developing countries than in developed countries.

However, if central bankers believe voters will reward preelectoral expansions, they may have incentives both to help right-wing parties engage in such expansions and to frustrate attempts by left-wing parties to do so. In effect, central bankers in such a world face an intertemporal tradeoff when right-wing governments are in power. They can push for the policy closest to their ideal point knowing that doing so hinders the right-wing party's prospects of reelection, or they can accept a more expansionary policy now in exchange for an increase in the probability that the government in power during nonelectoral times will be closer to its ideal point. ${ }^{1}$ In contrast, when left-wing parties are in power, a conservative central banker faces no such dilemma. Political preferences align with the Fed's well publicized commitment to price stability, since the political consequence of following through on that commitment is an increase in the probability that a government with an ideal point closer to its own will get elected. Thus, we can expect independent central banks to act like conservative independent central banks - but only when left-wing governments are in power. When the party the central bank favors is in power, the central bank should be more willing to accommodate preelectoral expansions: that is, it should act in the fashion traditionally associated with dependent central banks. This conditional accommodation is not evidence of a lack of independence. Far from it. It is evidence that the bank is using its independence to act on the fact that it is not indifferent.

\footnotetext{
${ }^{1}$ Another interpretation of the situation is that right-wing parties become "as if" they were a left-wing party as elections approach and central banks are merely responding to a new "reversion" point - the point that the right-wing government is implicitly threatening to implement if the central bank does not accommodate their temporarily expansionary wishes. However, if this was what was going on, the central bank should also behave in a more expansionary manner when elections draw near when left-wing parties control the government.
} 


\subsection{Possible Objections}

So far, we have assumed that independent central bankers have conservative preferences over monetary policy, but we have not explained why they would hold such preferences. We can invoke three reasons to justify this assumption. First, according to the logic of the Rogoff model, central bank independence is created to overcome the time inconsistency problem that plagues monetary policy. If those who grant independence to the bank do so for this reason, it would not make sense to appoint anyone other than an inflation hawk. Some might find it anachronistic to attribute this chain of reasoning to political principals operating decades before Kydland and Prescott, Barro and Gordon, and Rogoff, but there are other reasons why central bankers might be conservative. Monetary policy is a technical endeavor and exercising effective leadership of a central bank without a solid command of the economics of financial markets is highly unlikely. Thus, central bankers are likely to be drawn from an epistemic community with close ties to financial firms. In other words, central banks are prone to "industry capture." If one accepts the Posen (1995) argument that members of the financial community have reasons to have antiinflationary preferences, the selection process of central bankers makes it likely that they will be "conservative" in the Rogoffian sense. Finally, while Adolph (2004) is careful to point out that "independent" need not mean "conservative" he argues that central bankers may adopt ideological positions that will be favored by future employers. If the future employment possibilities for central bankers come overwhelmingly from financial firms, Adolph (combined with the Posen thesis) provides a forward-looking rationale for central bank conservatism.

Another possible objection is that while "left" and "right" wing may be appropriate labels for comparing socialist and business-oriented parties in western Europe, when viewed in a comparative context, Republicans and Democrats are best thought of as relatively similar "center-right" parties. This may be true, but all that is necessary for our model is that the parties differ in their propensity to represent antiinflationary constituencies. Our expectations are driven by the ordinal ranking of expected policies in the mind of the central bank, not the magnitude of the difference.

Yet, another concern may be raised about the impact of divided government. Fiscal policy, for example, is driven by both Congress and the President, so the Fed may care as much about who controls Congress as it cares about who controls the White House. And if that is true, ought we not be as concerned about the Congressional electoral calendar as the Presidential?

However, Alesina and Rosenthal (1995) present a model that views policy as a weighted average of the preferences of the executive and legislative branches. Their model predicts that "the policy outcome with a $\mathrm{D}$ [emocratic] president is always to the left of the policy outcome with an R[epublican] president (p. 48)." Thus, while divided government might have implications for the extent to which policy changes when the party of the president changes, it is not expected to disturb the ordinal ranking of policy outcomes. Therefore, it does not eliminate the intertemporal tradeoff conservative central bankers face when bargaining with a right-wing incumbent.

Furthermore, the empirical record suggests that the primary determinant of congressional elections is the party of the President (incumbent parties tend to lose seats) and so, even if the Fed wanted to influence congressional elections, the state of the economy has a relatively small impact. The Fed's problem would be even more complicated under divided government. Suppose Congress is controlled by the Democrats 
but Republicans control the Presidency. A preelectoral expansion would help incumbents in both parties, but if the link between the economy and the presidential vote is stronger than the link between the economy and congressional vote the Fed would have good reasons to focus on the former. ${ }^{2}$

Another objection to our argument may be that if conservative Fed chairmen aid in the election and reelection of Republican presidents, then we should not see Democratic presidents appointing inflation hawks. However, as we discussed above, our theoretical understanding of how central bank independence works relies on delegation to a conservative central banker. Therefore, to ask why Democrats would appoint conservative central bankers is akin to asking why they choose to support central bank independence. Although this question lies outside the scope of this article, it is useful to note that Democrats, in particular, can pay a high cost when they fail to appoint independent and hawkish central bankers.

Consider Carter's decision to appoint G. William Miller who, because of his Keynesian leanings, was thought to be more compatible with Carter's approach to the economy than Nixon appointee Arthur Burns. Within months, the dollar's value against the Deutsche Mark and Yen was in free fall and Carter announced a shift to an antiinflation policy in November, 9 months into Miller's term. In another 9 months (before Miller's first term was half over), Carter would appoint Paul Volcker, a wellknown inflation hawk, as the Fed Chairman. The former vicepresident of the New York Fed adopted a tight monetary policy aimed at "wringing out inflationary expectations" and restoring confidence in the dollar. Carter's goal was, in the words of Vice President Fritz Mondale, "to reassure financial markets", and it appears to have worked. Although Volcker's aggressive stance against inflation probably contributed to Carter's defeat, it is by no means obvious that the President's electoral fortunes would have been better served had the crisis Volcker's appointment was meant to curb been allowed to continue. In other words, it is possible to imagine something worse than tight monetary policy on the eve of an election.

Although it is true that this is just one anecdote, the reason we may not have more observations is that, in practice, reappointing a Fed chairman who was appointed by a predecessor from a different party appears to be almost automatic. ${ }^{3}$ Empirically, one thing we can do is see if controlling for the party that appointed the Fed Chairman influences our results. It does not (see appendix).

Finally, it is important to note that the results of our model would go through even if Democrats had a tendency to appoint less hawkish Fed chairmen, as long as they are not so dovish as to have ideal points closer to Democratic than Republican presidents. Were this to happen, our predictions would continue to be borne out in the subsample with Republican-appointed Chairmen, but not Democrat-appointed Chairmen. In fact, however, our results are at least as strong under Democrat-appointed Chairmen than Republican-appointed Chairmen (see appendix).

\section{EVIDENCE: IS THE FED A CONDITIONAL INFLATION HAWK?}

We explore the empirical evidence in support of the idea that the Fed is independent, but not indifferent in a number of ways. First, we examine whether the party of the

\footnotetext{
${ }^{2} \mathrm{We}$ are grateful to an anonymous reviewer for this point.

${ }^{3}$ The only other exception was Reagan's decision not to appoint Volcker a second time.
} 
incumbent president conditions the relationship between the Fed's policy instrument and the electoral cycle. We find that the Fed reduces the FFR as elections approach if the sitting president is a Republican. This is not the case under Democrats. In fact, there is some evidence that the FFR increases when elections draw near under Democratic presidents.

Then, we examine whether political factors condition the way the Fed responds to inflation and the output gap. We consistently find that in the run up to elections: the FFR (a) increases in response to inflation under Democrats but not under Republicans; and (b) decreases in response to shortfalls in output under Republicans but not under Democrats.

Finally, we show that the results just mentioned are robust with respect to numerous research design decisions we have made and we explore the evidence relevant to a competing perspective on the political sources of Fed behavior.

\subsection{The Conditional Link between the Electoral Calendar and the Fed Funds Rate}

The traditional political business cycle argument implies that if monetary policy is under the sway of politicians, interest rates ought to be lowered as elections draw near (solid lines in Panel (a) of Figure 2). Existing attempts to add central bank independence to this picture suggest that independence ought to dampen this effect - there should be little or no link between interest rates and the electoral calendar (dashed lines in Panel (a) of Figure 2). The traditional partisan model of monetary policy predicts that interest rates ought to be higher when right-wing governments are in power than when left-wing government are in power (solid lines in Panel (b) of Figure 2). If the central bank is a neutral inflation hawk, then partisan differences in interests ought to remain, though at a lower rate reflecting the unconditional influence of an independent central bank (dashed lines in Panel (b) of Figure 2). Our model, however, predicts a relationship between the electoral calendar and interest rates under central bank independence that is distinct from both of these alternatives. If the central bank supports the electoral and reelectoral efforts of right-wing parties, interest rates ought to decrease (increase) as elections draw near under right-wing (left-wing) governments (dashed lines in Panel (c) of Figure 2). In contrast, in the absence of central bank independence, our model predicts the same behavior as the traditional PBC model does (solid lines in Panel (c) Figure 2). In this section, we use data on the Federal Funds Rate to evaluate this claim.

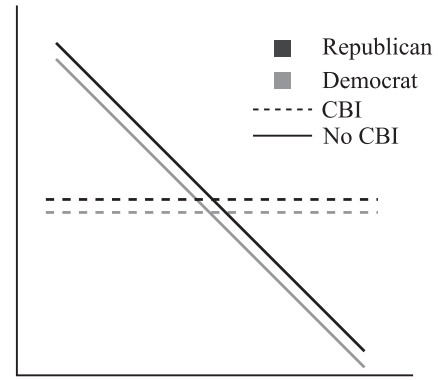

(a) Electoralist

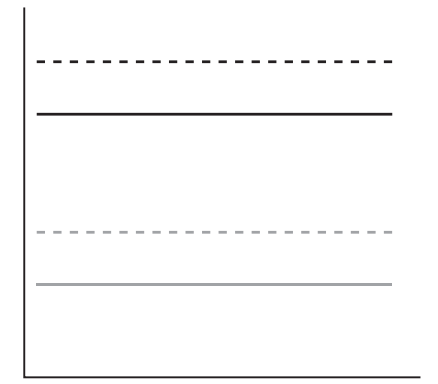

(b) Partisan

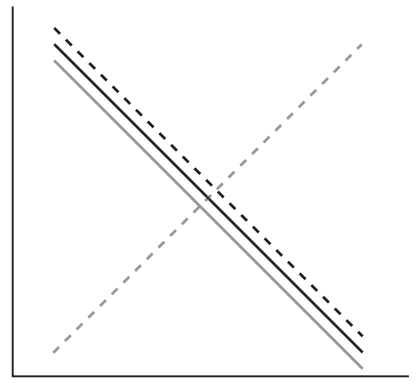

(c) Strategic central banker

Figure 2. Hypothesized link between interest rates and the electoral calendar. 


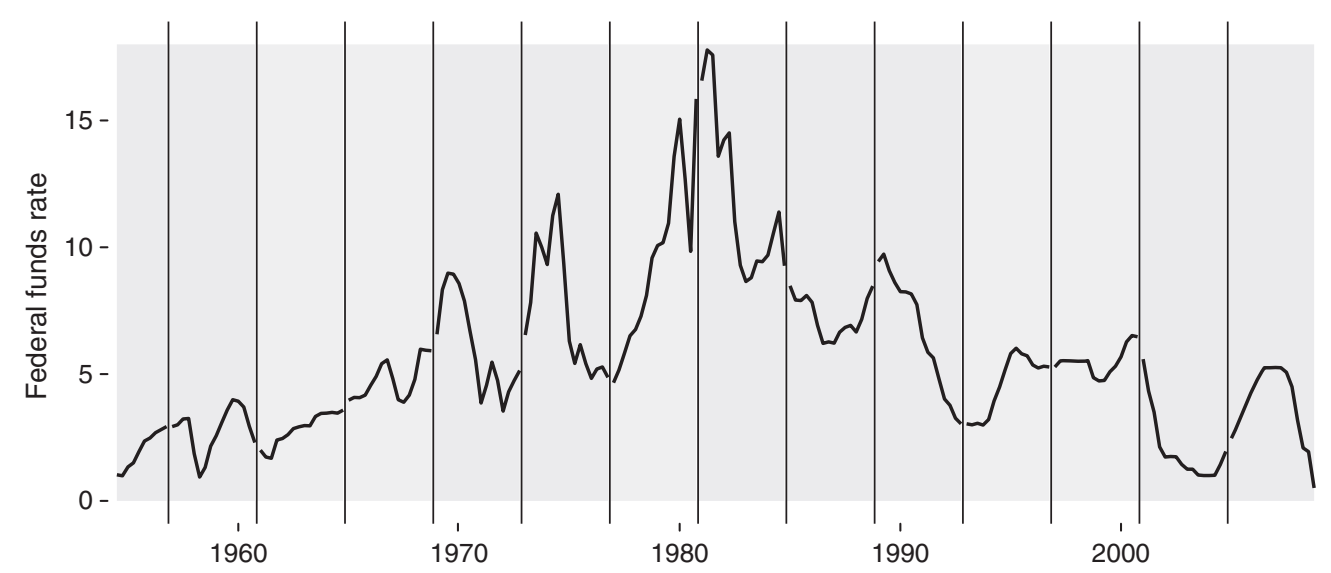

Figure 3. Federal funds rate over time. Vertical bars correspond to presidential elections. The red shading indicates periods of Republican rule in the White House.

Figure 3 traces the evolution of the FFR since Eisenhower's first term in office. ${ }^{4}$ The difference between the Democrat and the Republican periods is striking. For every Democratic term in office, the interest rate path ends at a higher level than it started. For every Republican president's term, it ends at a lower rate than it started. The Federal funds rate climbs during each Democratic administration and falls, often precipitously, before Republican incumbents come up for reelection.

Although the data in Figure 3 are visually compelling, one objection may be that the Fed is behaving differently under Democrats and Republicans because underlying macroeconomic conditions differ when partisan control varies. To ensure that the pattern identified above is not driven by differences in the underlying economic conditions to which the Fed is responding, it is important to control for these underlying conditions. To that end, we estimate models of the following form:

$$
\begin{aligned}
\text { FFR }_{t}= & \beta_{E} \text { Election }+\beta_{D} \text { Democrat }+\beta_{E D} \text { Election }{ }^{*} \text { Democrat } \\
& +\beta_{Y} \text { YGap }+\beta_{\pi} \text { Inflation }+\beta_{F} \text { FFR }_{t-1}+\Omega P+\epsilon
\end{aligned}
$$

FFR is the effective federal funds rate. Election is an election counter which equals 0 in the period that immediately follows a presidential election. Election is then incremented by one in every subsequent quarter until it reaches 15 . Democrat is a dummy variable equal to one when a Democratic president is in office and 0 otherwise. YGap is the output gap, defined as the percentage deviation of the real GDP from real potential GDP. ${ }^{5}$ We use the annualized quarterly change in the Consumer Price Index (for all urban consumers) as our measure of inflation. $P$ is a vector of dummy variables that correspond to each presidential administration ${ }^{6}$. Unless stated otherwise, all

\footnotetext{
${ }^{4}$ Data on the FFR were obtained from the FRED database, published by the St. Louis Fed.

${ }^{5}$ Real potential GDP represents real GDP under conditions of full employment. Estimates are from the Congressional Budget Office.

${ }^{6}$ Including dummy variables for each presidential administration allows for structural breaks in the monetary regime, that is, it allows us to relax the assumption that the Fed's target interest rate, conditional on inflation and output gap, remained constant throughout the 1951-2008 period. A side effect of this modeling choice is that the value of the Democrat coefficient will be sensitive to which presidential dummy is omitted, but this is of no substantive significance because $D$ does not enter in the marginal effects that interest us.
} 
macroeconomic data are from the FRED database at the Federal Reserve Bank of St. Louis. All variables are measured at quarterly intervals. Our tests cover the period from July 1954 (the earliest point when the Fed Funds Rate is available) to October 2008 (the end of the last complete electoral period).

If our argument is correct, the coefficient on the election variable, which captures the estimated effect of a movement toward an election when Democrat $=0$, ought to be negative and statistically significant. The coefficient on the interaction term should also be positive and large compared with the coefficient on election. Table 1 shows that this is the case in Model 1. The coefficient on Election is negative and statistically significant and the coefficient on the interaction is positive and roughly twice as large as the coefficient on Election. This model essentially summarizes the plot in Figure 3: on average interest rates drop over the course of Republican administrations, but increase over the course of Democratic administrations.

Figure 4 graphically displays the estimated marginal effect of a change in electoral quarter in Democratic and Republican administrations based on Model 1. Note that the confidence interval around the estimated effect under Republican administrations is negative, but the confidence interval around the estimated effect under a Democratic administration is positive. Thus, according to Model 1, interest rates go down as elections draw near when Republicans control the White House, but they go up when elections draw near when Democrats control the White House. The magnitude of the changes involved are also substantively significant. For example, Model 1 suggests that the Fed Funds Rate is expected to go down by about six basis points each quarter as elections approach when the Republicans control the White House and up by about the same amount under Democrats. To put these estimated changes in

Table 1. Relationship between Election Cycles and the Federal Funds Rate (FFR), Conditional on the Party of the Incumbent President

\begin{tabular}{lcccc}
\hline & Model 1 & Model 2 & Model 3 & Model 4 \\
\hline Election & $-0.062^{* *}$ & $-0.062^{* *}$ & $-0.035^{*}$ & $-0.039^{*}$ \\
& $(0.020)$ & $(0.019)$ & $(0.018)$ & $(0.018)$ \\
Democrat & $0.748^{\dagger}$ & $0.936^{*}$ & $0.633^{*}$ & $0.577^{\dagger}$ \\
& $(0.380)$ & $(0.366)$ & $(0.312)$ & $(0.323)$ \\
Election $\times$ democrat & $0.120^{* *}$ & $0.112^{* *}$ & 0.068 & 0.070 \\
& $(0.039)$ & $(0.038)$ & $(0.046)$ & $(0.046)$ \\
$\pi$ & & $0.156^{* * *}$ & $0.115^{* *}$ & $0.119^{* *}$ \\
& & $(0.040)$ & $(0.039)$ & $(0.038)$ \\
Y-gap & & & $0.207^{* * *}$ & $0.217^{* * *}$ \\
& & & $(0.057)$ & $(0.056)$ \\
Surplus/GDP & & & & -0.079 \\
& & & $0.051)$ \\
FFR & & & $0.727^{* * *}$ & $0.749^{* * *}$ \\
& & $(0.066)$ & $(0.058)$ & $(0.063)$ \\
$N$ & $(0.063)$ & 217 & 217 & 217 \\
$R^{2}$ & 217 & 0.985 & 0.987 & 0.987 \\
Adj. $R^{2}$ & 0.983 & 0.983 & 0.986 & 0.986 \\
Resid. sd & 0.982 & 0.844 & 0.781 & 0.780 \\
\hline
\end{tabular}

Ordinary least squares regression with FFR as dependent variable. Administration dummies omitted.

Robust standard errors in parentheses.

${ }^{\dagger} p<.10 ;{ }^{*} p<.05 ;{ }^{* *} p<.01 ;{ }^{* * *} p<.001$. 


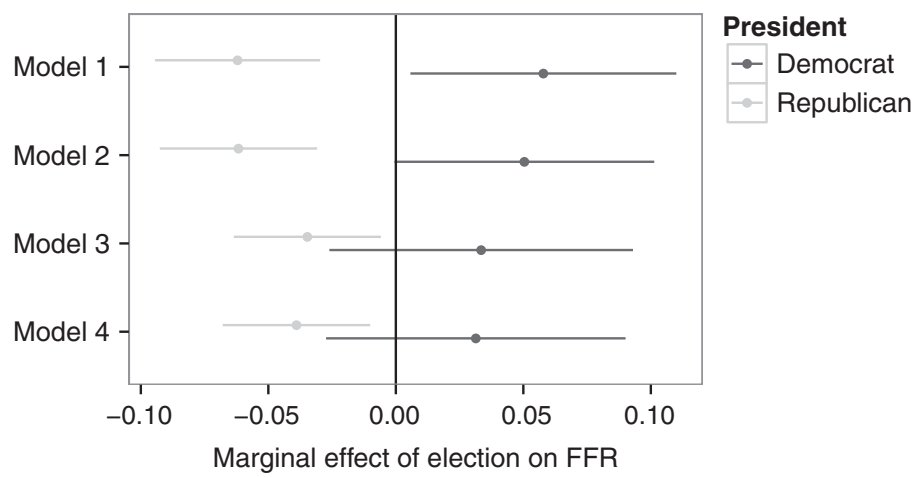

Figure 4. Marginal effect associated with moving one quarter closer to an election under Republican and Democratic Presidents. Lines indicate 90\% confidence intervals.

perspective it is useful to remember that the median quarterly change in the Fed Funds Rate during this period is two basis points.

It is possible, however, that this observed difference in Fed behavior under Democratic and Republican presidents could be explained by differences in macroeconomic conditions associated with Democratic or Republican rule. Thus, in Models 2 and 3, we control for macroeconomic conditions by including the two Taylor-rule variables: output gap and inflation. Evidence that the Fed acts differently under Republican and Democratic presidents is generally robust to the inclusion of a control for inflation (Model 2), and inflation and the output gap (Model 3) - although the interaction term is no longer statistically significant in the latter case. Figure 4 shows that the marginal effect of elections on the FFR when Republicans control the White House is negative in models 2 and 3. In contrast, the marginal effect of elections is either positive (Model 2) or indistinguishable from zero (Model 3) when Democrats control the White House.

Some might argue that a politically disinterested Fed behaves in systematically different ways under Democratic and Republican presidents because it is responding to partisan differences in fiscal policy. For example, if one believed that Democrats were prone to larger deficits, a Fed that is an inflation hawk might need to engage in monetary contractions to counter this loose fiscal policy. Although we believe there is little evidence that Democrats produce larger budget deficits, we control for Surplus/GDP to rule out this alternative explanation. ${ }^{7}$ Both Table 1 and Figure 4 show that the results change little with the addition of this control. As was the case for Model 3, the estimated marginal effect of an increase in electoral proximity is negative and statistically significant when the Republicans control the White, but positive, albeit not significantly so, when Democrats control the White House.

\subsection{The Fed's Conditional Reaction Function}

The previous section implicitly assumes that interest rates are driven primarily by the electoral calendar, modified by the party of the president. This is an extreme version of

\footnotetext{
${ }^{7}$ Data on the federal government surplus are only available at yearly intervals, but our other variables are measured quarterly. We used cubic spline interpolation to create a quarterly Surplus/GDP measure. In another specification, omitted here for brevity, we used a quarterly measure of federal government expenditures in lieu of the surplus variable. The results were substantively unchanged.
} 
our argument. More plausibly, perhaps, the Fed's reaction function may be fundamentally similar to the Taylor rule, but strategic considerations may cause the Fed to deviate from the textbook policies we would associate with a politically disinterested central bank. If the Fed were operating according to the Taylor rule, it would raise interest rates in response to increased inflation and lower interest rates in response to a decrease in the output gap. Empirically, we might capture such behavior with a model such as:

$$
\mathrm{FFR}_{t}=\alpha_{Y} \mathrm{YGap}+\alpha_{\pi} \text { Inflation }+\alpha_{F} \mathrm{FFR}_{t-1}+\epsilon,
$$

with the expectation that $a_{Y}>0, a_{\pi}>0$. If the Fed behaves as an inflation hawk, the coefficient on the output gap would be close to zero and the coefficient on inflation would be large. If the Fed is more concerned about shortfalls in output than inflation, the converse would be true - the coefficient on the output gap would be large and the coefficient on inflation would be close to zero. The traditional PBC model would predict that a dependent central bank would act less and less like an inflation hawk as elections draw near. Thus, $a_{Y}$ and $a_{\pi}$ are conditional on the electoral calendar. In addition, our argument suggests that the conditioning effect of the electoral calendar is different when Republicans control the White House than when Democrats do. The appropriate conditional model, therefore, is:

$$
\begin{aligned}
\text { FFR }_{t}= & \beta_{\pi} \text { Inflation }+\beta_{\pi E} \text { Inflation }{ }^{*} \text { Election }+\beta_{\pi D} \text { Inflation }{ }^{*} \text { Democrat } \\
& +\beta_{\pi E D} \text { Inflation }{ }^{*} \text { Election }{ }^{*} \text { Democrat } \\
& +\beta_{Y} \text { YGap }+\beta_{Y E} \text { YGap * Election }+\beta_{Y D} \text { YGap }^{*} \text { Democrat } \\
& +\beta_{Y D E} \text { YGap }{ }^{*} \text { Democrat }{ }^{*} \text { Election } \\
& +\beta_{E} \text { Election }+\beta_{D} \text { Democrat }+\beta_{D E} \text { Democrat }{ }^{*} \text { Election } \\
& +\beta_{F} \text { FFR }_{t-1}+\Omega P+\epsilon
\end{aligned}
$$

and the conditional effects of changes in inflation are given by:

$$
\frac{\partial \mathrm{FFR}}{\partial \text { Inflation }}=\beta_{\pi}+\beta_{\pi E} \text { Election }+\beta_{\pi D} \text { Democrat }+\beta_{\pi E D} \text { Election * Democrat, }
$$

when Republicans are in office $(D=0)$ this simplifies to

$$
\frac{\partial \mathrm{FFR}}{\partial \text { Inflation } \mid \text { Democrat }=0}=\beta_{\pi}+\beta_{\pi E} \text { Election, }
$$

which is a straight line that summarizes how electoral proximity influences the relationship between inflation and interest rates when Republicans control the White House. If our argument is correct, the Fed ought to respond to increased inflation less aggressively as Republican incumbents draw closer to reelection. Thus, the slope parameter $\left(\beta_{\pi E}\right)$ ought to be negative, or at least not positive. The model in the first column in Table 2 suggests this is the case - the interaction term Election $\times \pi$ is negative and statistically significant. Note also that the coefficient on $\pi$ is positive and statistically significant. This suggests that $a_{1}$ of the Taylor rule (1) is positive - as we would expect if the Fed is an inflation hawk - in the period furthest away from the next election (i.e., when Election $=0$ ). 
Table 2. Fed Reaction to Changes in Output Gap and Inflation, Conditional on Electoral Cycles and Party of the President

\begin{tabular}{|c|c|c|c|}
\hline & $\pi$ & $\pi_{t}-\pi_{t-4}^{e}$ & $\pi^{e}$ \\
\hline \multirow[t]{2}{*}{$\pi$} & $0.217^{* *}$ & 0.144 & $0.417^{*}$ \\
\hline & $(0.074)$ & $(0.119)$ & $(0.165)$ \\
\hline \multirow[t]{2}{*}{$\pi \times$ election } & $-0.016^{*}$ & -0.011 & $-0.028^{\dagger}$ \\
\hline & $(0.006)$ & $(0.017)$ & $(0.015)$ \\
\hline \multirow{2}{*}{$\pi \times$ democrat } & -0.594 & $-0.528^{*}$ & -0.631 \\
\hline & $(0.393)$ & $(0.205)$ & $(0.413)$ \\
\hline \multirow[t]{2}{*}{$\pi \times$ election $\times$ democrat } & $0.068^{*}$ & $0.080^{* *}$ & $0.083^{* *}$ \\
\hline & $(0.031)$ & $(0.028)$ & $(0.031)$ \\
\hline \multirow[t]{2}{*}{ Y-gap } & 0.069 & 0.001 & 0.080 \\
\hline & $(0.119)$ & $(0.149)$ & $(0.124)$ \\
\hline \multirow[t]{2}{*}{ Y-gap $\times$ election } & $0.027^{\dagger}$ & $0.037^{*}$ & $0.024^{\dagger}$ \\
\hline & $(0.015)$ & $(0.018)$ & $(0.013)$ \\
\hline \multirow[t]{2}{*}{ Y-gap $\times$ democrat } & 0.267 & 0.165 & 0.172 \\
\hline & $(0.172)$ & $(0.164)$ & $(0.154)$ \\
\hline \multirow[t]{2}{*}{ Y-gap $\times$ election $\times$ democrat } & -0.028 & $-0.059^{\dagger}$ & -0.024 \\
\hline & $(0.021)$ & $(0.032)$ & $(0.020)$ \\
\hline \multirow[t]{2}{*}{ Election } & 0.009 & $-0.075^{*}$ & 0.052 \\
\hline & $(0.021)$ & $(0.030)$ & $(0.063)$ \\
\hline \multirow[t]{2}{*}{ Democrat } & $2.476^{*}$ & $1.135^{* *}$ & $2.775^{\dagger}$ \\
\hline & $(0.998)$ & $(0.417)$ & $(1.462)$ \\
\hline \multirow[t]{2}{*}{ Election $\times$ democrat } & $-0.128^{*}$ & $0.203^{*}$ & $-0.229^{* *}$ \\
\hline & $(0.062)$ & $(0.092)$ & $(0.086)$ \\
\hline \multirow[t]{2}{*}{ Surplus/GDP } & 0.014 & 0.018 & 0.054 \\
\hline & $(0.059)$ & $(0.069)$ & $(0.067)$ \\
\hline \multirow[t]{2}{*}{$\mathrm{FFR}_{t-1}$} & $0.573^{* * *}$ & $0.612^{* * *}$ & $0.525^{* * *}$ \\
\hline & $(0.108)$ & $(0.108)$ & $(0.125)$ \\
\hline$N$ & 217 & 192 & 196 \\
\hline$R^{2}$ & 0.990 & 0.989 & 0.990 \\
\hline Adj. $R^{2}$ & 0.988 & 0.988 & 0.989 \\
\hline Resid. sd & 0.702 & 0.766 & 40.732 \\
\hline
\end{tabular}

Ordinary least squares regression with FFR as dependent variable. Administration dummies omitted. Robust standard errors in parentheses.

${ }^{\dagger} p<.10 ;{ }^{*} p<.05 ;{ }^{* *} p<.01 ;{ }^{* * *} p<.001$.

When Democrats control the White House five simplifies to:

$$
\frac{\partial \mathrm{FFR}}{\partial \text { Inflation|Democrat }=1}=\left[\beta_{\pi}+\beta_{\pi D}\right]+\left[\beta_{\pi E}+\beta_{\pi E D}\right] \text { Election. }
$$

If out argument is correct, the Fed should respond to increased inflation more aggressively as elections draws near. Thus, the slope parameter $\left(\beta_{\pi E}+\beta_{\pi E D}\right)$ ought to be positive. It is easy to see that in Table 2 the sum of the coefficients $\pi \times$ Election $+\pi \times$ Democrat $\times$ Election $=0.052$. A Wald test reveals that this slope is statistically distinguishable from zero at the 0.10 confidence level.

The conditional relationship between the Fed Funds Rate and inflation can be more clearly seen graphically. The top left-hand panel in Figure 5 plots equations 3 (in red) and 4 (in blue) across the 16 quarters of a presidential administration.

The positive slope on the blue line suggest that when a Democrat is in office the Fed acts more like an inflation hawk as elections draw near. Specifically, in these cir- 


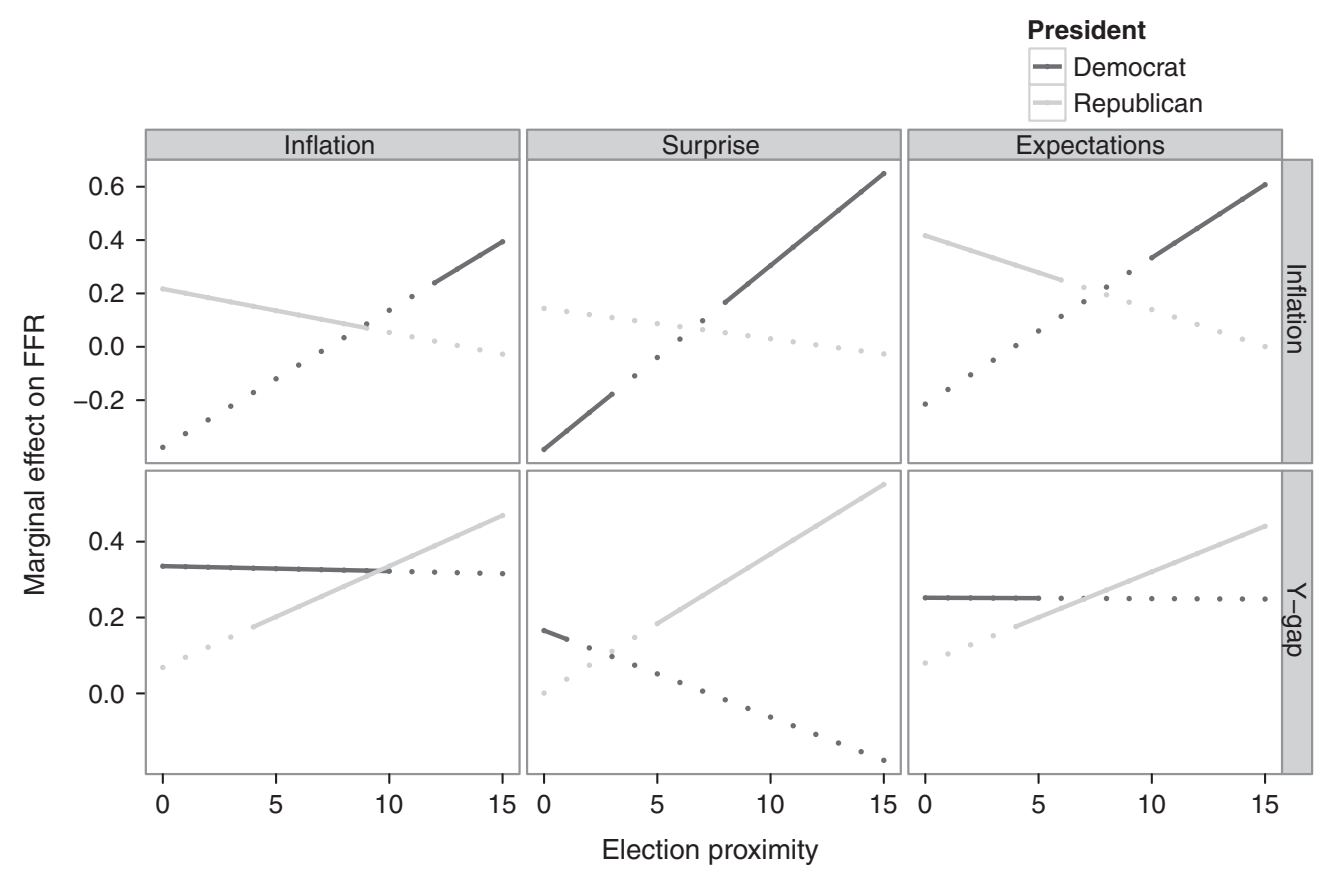

Figure 5. Marginal effect of inflation and output gap on the federal funds rate, conditional on the election calendar under Republican (red) and Democratic (blue) presidents. Solid lines indicate statistical significance at the $\alpha=0.05$ level.

cumstances the Fed places a greater weight on hitting its inflation target. In contrast, the negative slope on the red line suggest that the association between interest rates and inflation goes to zero as Republican incumbents near reelection. By comparing equations 6 and 7, we can see that the difference in the slope of these two lines is captured by the value of the $\pi \times$ Democrat $\times$ Election coefficient in Table 2 . Note that this is consistently positive and statistically significant. This suggests that Election affects the relationship between inflation and the Fed Funds Rate differently when Democrats and Republicans control the White House. Furthermore, we can see that the estimated marginal effect of a change in inflation is positive when Republicans control the White House and elections are far off (Election < 9) and when Democrats control the White House and elections draw near (Election $>12$ ). It is worth noting that the canonical Taylor rule coefficients on the inflation and output gaps are both 0.5 , which suggests that the magnitude of our estimates are not unreasonable. What is interesting is that the Fed tends to pursue one of these goals at at time, not both. And which one they pursue depends on the party of the President.

Our model also makes conditional statements about the relationship between interest rates and the output gap. Based on equation 4, the conditional effect of a change in the output gap is given by

$$
\frac{\partial \mathrm{FFR}}{\partial \mathrm{YGap}}=\beta_{Y}+\beta_{Y E} \text { Election }+\beta_{Y D} \text { Democrat }+\beta_{Y E D} \text { Election * Democrat, }
$$


when Republicans are in office $(D=0)$ this simplifies to

$$
\frac{\partial \mathrm{FFR}}{\partial \text { YGap } \mid \text { Democrat }=0}=\beta_{Y}+\beta_{Y E} \text { Election, }
$$

which is the equation for the red line in the bottom left-hand panel of Figure 2. Note that the slope of this line is the coefficient on the interaction between the output gap and electoral proximity which is positive and statistically significant at the 0.10 level in column one of Table 2. This suggests that as elections draw near the Fed places greater emphasis on hitting its output target. In fact, the bottom left-hand panel of Figure 5 shows that, with the exception of the four quarter period after an election, there is a statistically distinguishable association between the Fed Funds Rate and the output gap when the Republicans control the White House. In contrast, the postelection honeymoon period is the only time when such a relationship exists when the Democrats are in the White house.

An examination of the results in the first column of Table 2 and the left-hand panel of Figure 5, therefore, supports the notion that the Fed is a conditional inflation hawk. When the Democrats control the White House, the Fed appears to pay increased attention to hitting its inflation target and a decreased emphasis on its output target as elections draw near. When Republicans are in office the Fed shifts its attention in the opposite direction.

The evidence shown above is consistent with our argument that the Fed is not politically indifferent but not consistent with any other story we can think of. Below, we will compare these results to the expectations of competing theories about the link between monetary policy and electoral politics. However, before doing so, it is important to consider whether our central results are robust.

\subsection{Robustness Checks}

Although we think the above results are important and provocative, we need to establish whether they are driven by research design choices. Specifically, we examine whether the results depend on a) the nature of the Fed's reaction function with respect to inflation; b) influential observations; c) the timing of Fed policy; d) unmodeled heterogeneity deriving from unique characteristics of individual Fed chairmen; e) decisions about how to measure inflationary expectations; or f) decisions about how to model time dynamics.

Inflation, Inflation Surprise, Inflation Expectations Up to this point, our discussion has assumed that the underlying model the Fed uses to set policy is one in which the Fed responds to current changes in the economy in a fashion similar to the Taylor rule - specifically, the Fed alters interest rates in response to the current inflation rate and the current output gap. However, a more standard treatment (Barro and Gordon, 1983) would hold that the Fed is trying to minimize a loss function similar to the one we introduced to explain voter preferences (equation 1). In this loss function, the Fed would be responding to the size of the output gap and the size of the inflationary surprise - that is the gap between realized inflation and the amount of inflation that had been forecast. If realized inflation exceeded expected inflation, an inflation hawk would be particularly eager to raise interest rates. To capture this possibility, column 2 of Table 2 uses the gap between the current inflation rate and the Fed's forecast for 
the current quarter from the previous year. An examination of the central panel of Figure 5 shows that the relationship between the size of the inflationary surprise and the Fed Funds Rate is very similar to the relationship between inflation and the Fed Funds Rate - the Fed places great weight on hitting its inflation target when elections approach if and only if the Democrats control the White House. The red line in the lower center panel shows that when Republicans control the White House the Fed becomes more responsive to changes in the output gap as election draw near, but the blue line shows that when Democrats control the White House the Fed's response to changes in the output gap is statistically distinguishable from zero only in the postelection honeymoon period. Thus, using this more refined definition of the inflation target has an effect on the relationship between the Fed Funds Rate and the output gap produces results that are qualitatively similar to the results previously presented.

Next, it is worth considering the possibility that the Fed is a politically indifferent inflation hawk, but that it holds different expectations about future inflation under Republicans and Democrats. Specifically, if a politically indifferent Fed expects Democrats to adopt more inflationary policies in the run-up to elections, it may have incentives to raise interest rates. We examine this possibility in column 3 of Table 2, where we substitute a measure of inflationary expectations for the inflation variable used in column 1. We find that our results change very little - the patterns in the right-handside panel of Figure 5 are essentially the same as in the left-handside panel. That is, whether one believes the Fed is responding to the current inflation rate or to surprise inflation, the Fed behaves as a conditional inflation hawk.

The Volcker Effect? It is well known that Chairman Paul Volcker played an important role in "wringing out inflationary expectations" during the later part of the Carter and the early part of the first Reagan administration. This pronounced monetary contraction in the period just before a Democrat stood for reelection and just after a Republican came to power fits our argument so well that it may be driving our results. To examine this possibility, Table 3 replicates the models from Table 2 using a sample that drops the observations when Volcker was chairman. Notice that the coefficients in this table are qualitatively similar to those in Table 2. Figure 6 shows that the key elements of our central results are robust to the exclusion of the Volcker years: interest rates are linked to inflation as Democrats approach reelection, but not when Republicans control the White House, and interest rates are increasingly linked to the output gap as Republicans near the end of their term, but not when Democrats do. That said, it should be pointed out that the magnitude of the effects are smaller when the Volcker years are removed from the sample - especially when it comes to the link between Fed policy and inflation (note the difference in scale on the y-axis in the top panels of Figures 5 and 6).

The notion that our results may be driven by peculiarities related to Volcker's tenure as chairman raises the question of whether there are aspects of other chairs' tenures that introduce unmodeled heterogeneity. To control for this possibility we reestimated all our models with Chairman dummies and our results were substantially unchanged (see web appendix).

Timing of Monetary Policy If the effect of monetary policy on growth is not instantaneous, manipulating the FFR just before an election is unlikely to affect the economy in time to influence voters. Similarly, Bernanke's announcement of a third round of 
Table 3. Fed Reaction to Changes in Output Gap and Inflation, Conditional on Electoral Cycles and Party of the President. Volcker Chairmanship Omitted

\begin{tabular}{|c|c|c|c|}
\hline & $\pi$ & $\pi_{t}-\pi_{t-4}^{e}$ & $\pi^{e}$ \\
\hline \multirow[t]{2}{*}{$\pi$} & $0.137^{\dagger}$ & 0.109 & 0.318 \\
\hline & $(0.080)$ & $(0.089)$ & $(0.202)$ \\
\hline \multirow[t]{2}{*}{$\pi \times$ election } & -0.008 & -0.007 & -0.016 \\
\hline & $(0.007)$ & $(0.010)$ & $(0.020)$ \\
\hline \multirow[t]{2}{*}{$\pi \times$ democrat } & $-0.301^{* *}$ & $-0.303^{*}$ & $-0.475^{*}$ \\
\hline & $(0.111)$ & $(0.135)$ & $(0.216)$ \\
\hline \multirow[t]{2}{*}{$\pi \times$ election $\times$ democrat } & $0.034^{* * *}$ & $0.045^{* *}$ & $0.047^{*}$ \\
\hline & $(0.010)$ & $(0.016)$ & $(0.021)$ \\
\hline \multirow[t]{2}{*}{ Y-gap } & $0.184^{\dagger}$ & 0.129 & 0.164 \\
\hline & $(0.102)$ & $(0.133)$ & $(0.124)$ \\
\hline \multirow[t]{2}{*}{ Y-gap $\times$ election } & 0.013 & 0.019 & 0.014 \\
\hline & $(0.012)$ & $(0.015)$ & $(0.011)$ \\
\hline \multirow[t]{2}{*}{ Y-gap $\times$ democrat } & 0.051 & 0.068 & 0.038 \\
\hline & $(0.110)$ & $(0.139)$ & $(0.130)$ \\
\hline \multirow[t]{2}{*}{$Y$-gap $\times$ election $\times$ democrat } & -0.020 & -0.027 & -0.019 \\
\hline & $(0.014)$ & $(0.017)$ & $(0.013)$ \\
\hline \multirow[t]{2}{*}{ Election } & -0.005 & $-0.054^{*}$ & 0.013 \\
\hline & $(0.027)$ & $(0.022)$ & $(0.084)$ \\
\hline \multirow[t]{2}{*}{ Democrat } & $1.643^{* * *}$ & $1.023^{* *}$ & $2.058^{* * *}$ \\
\hline & $(0.417)$ & $(0.381)$ & $(0.490)$ \\
\hline \multirow[t]{2}{*}{ Election $\times$ democrat } & -0.038 & $0.110^{* *}$ & -0.092 \\
\hline & $(0.032)$ & $(0.036)$ & $(0.086)$ \\
\hline \multirow[t]{2}{*}{ Surplus/GDP } & -0.064 & -0.058 & -0.056 \\
\hline & $(0.070)$ & $(0.083)$ & $(0.088)$ \\
\hline \multirow[t]{2}{*}{$\mathrm{FFR}_{t-1}$} & $0.697^{* * *}$ & $0.701^{* * *}$ & $0.655^{* * *}$ \\
\hline & $(0.086)$ & $(0.093)$ & $(0.112)$ \\
\hline$N$ & 185 & 160 & 164 \\
\hline$R^{2}$ & 0.991 & 0.991 & 0.991 \\
\hline Adj. $R^{2}$ & 0.989 & 0.989 & 0.990 \\
\hline Resid. sd & 0.559 & 0.587 & 0.569 \\
\hline
\end{tabular}

Ordinary least squares regression with FFR as dependent variable. Administration dummies omitted. Robust standard errors in parentheses.

${ }^{\dagger} p<.10 ;{ }^{*} p<.05 ;{ }^{*} p<.01 ;{ }^{* * *} p<.001$.

quantitative easing in September 2012 may seem pro-Democrat, but the real effects of this policy are unlikely to take place until after the election.

If anecdotes like this are part of a pattern, then tests of our theory that are based on full electoral cycles will understate the strength of association between electoral cycles, the party of the President, and the FFR. Indeed, when we replicate the models shown above but exclude the last quarter or the last two quarters of each election cycle, our results are strengthened (see web appendix).

Measuring Inflationary Expectations There is also the possibility that our central results depend on the way inflationary expectations are measured. We reestimated the inflation surprise model in the second column of Table 2 with three alternative measures of inflationary expectations: Households is the median expected price change (12 months) obtained from a household survey conducted by the Survey Research Center at the University of Michigan; Forecasters is the median 1 year inflation 


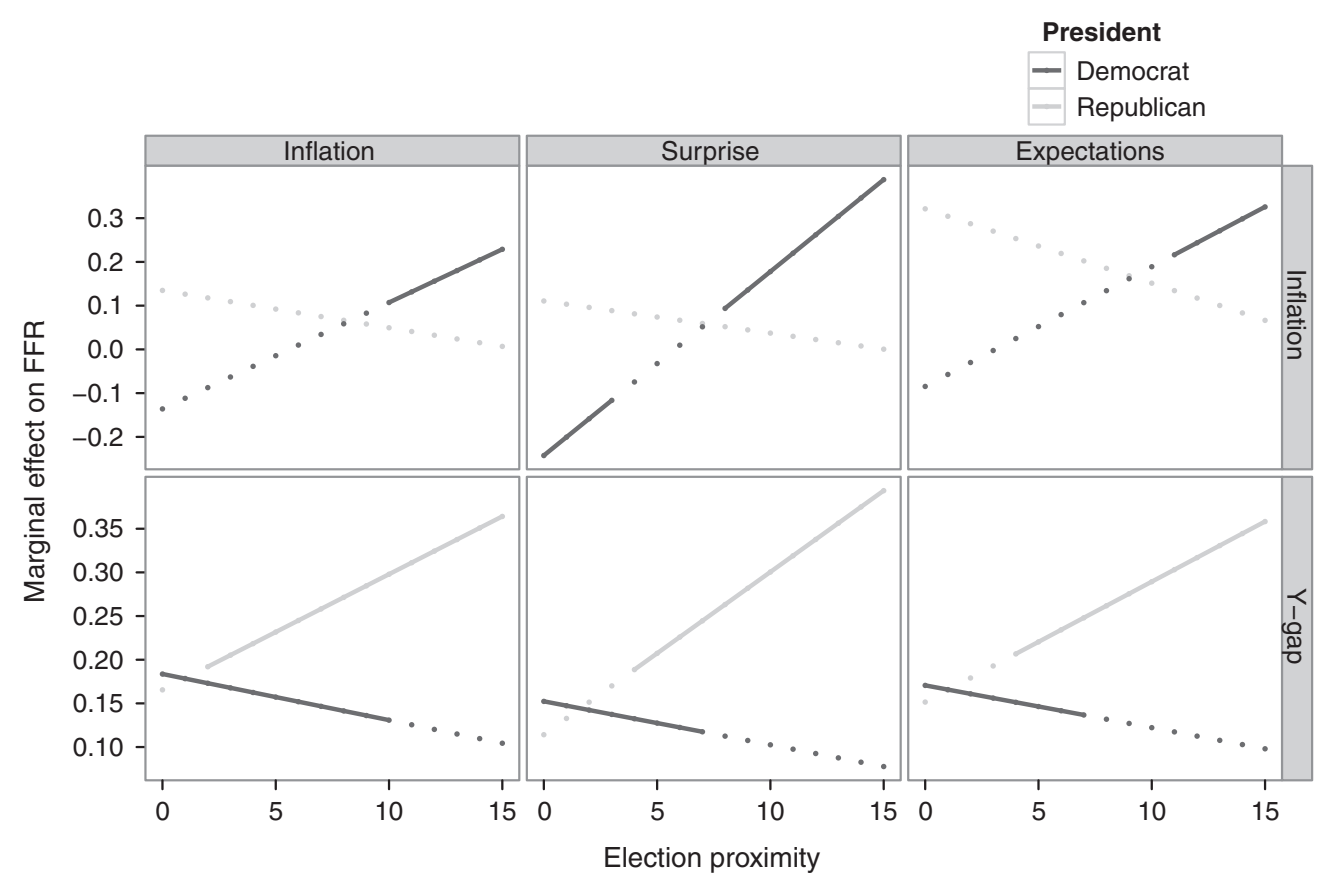

Figure 6. Marginal effect of inflation and output gap on the federal funds rate, conditional on the election calendar under Republican (red) and Democratic (blue) presidents omitting the Chairmanship of Paul Volcker. Solid lines indicate statistical significance at the $\alpha=0.05$ level.

expectation from the Survey of Professional Forecasters (Philadelphia Fed); and Cleveland Fed is a model-based measure of inflationary expectations computed for the 1 -year horizon by the Cleveland Fed. A graphical representation of the results is displayed in Figure 7 (see web appendix for a table of results). Notice that in general the results change little. The output gap appears to drive policy when Republicans are in the White House and facing reelection, and inflation drives policy when the Democrats are in the White House and facing reelection or Republicans are in the White House and enjoying a postelection honeymoon. The biggest change in results is a general decline in statistical significance, which can probably be attributed to a decline in sample size due to the unavailability of the alternative measures for early time periods.

Dynamics Breusch-Godfrey tests show that there remains residual autocorrelation in most of the models shown above. This suggests that including a single lagged dependent variable may be inadequate to capture the time dynamics correctly. To address this issue, we reestimated all models with three alternative specifications. The first includes additional lagged dependent variables, the second includes an AR(1) term, and the third includes autoregressive and moving average terms with order determined by the algorithm of Hyndman and Khandakar (2008). Our substantive conclusions remained unchanged. Full results are reported in the web appendix. 


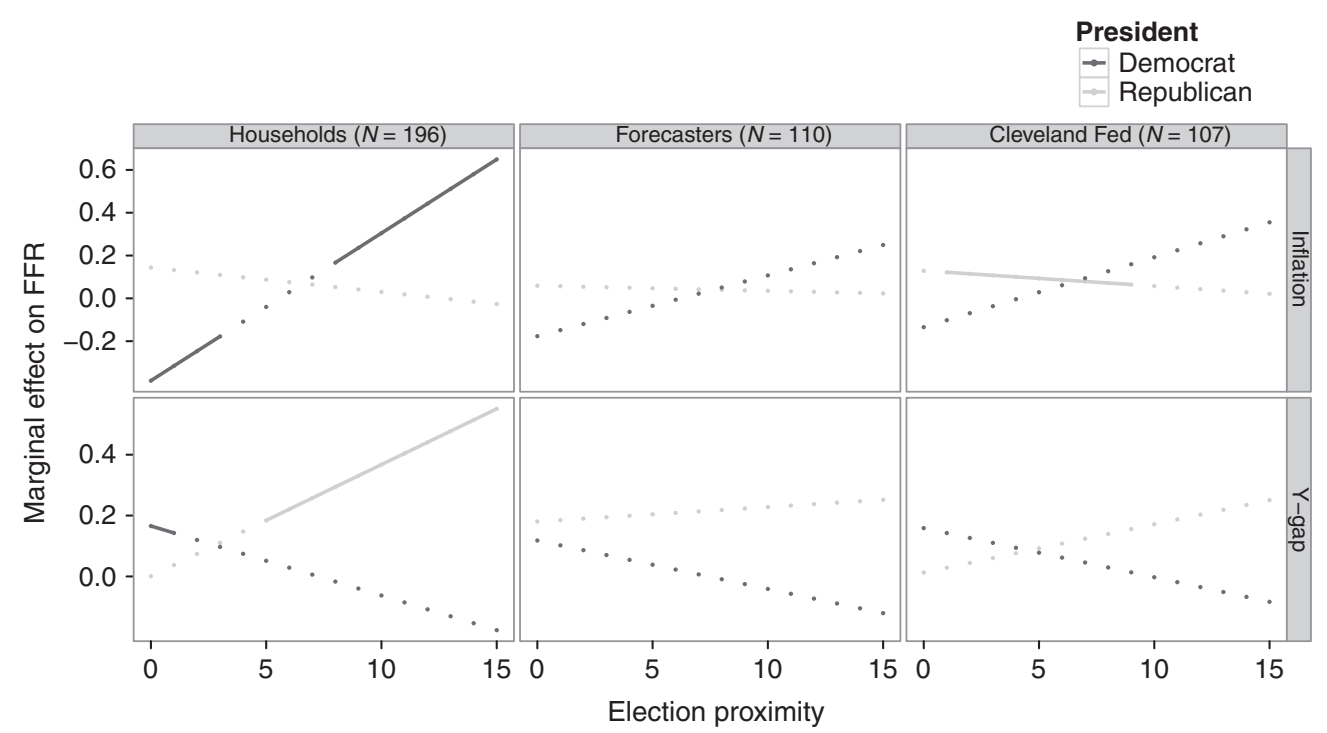

Figure 7. Marginal effect of an inflationary surprise and output gap on the federal funds rate, conditional on the election calendar under Republican (red) and Democratic (blue) presidents using alternative measures of inflationary expectations. Solid lines indicate statistical significance at the $\alpha=0.05$ level.

\subsection{Alternative Explanations}

We now consider two approaches to the way the party of the president might influence monetary policy. First, we address the possibility that our result might be explained by the "rational partisan cycle" developed by Alesina and Rosenthal (1995). We argue that our argument is broadly consistent with Alesina and Rosenthal's finding that Democrats (Republicans) preside over macroeconomic expansions (contractions) after coming to office. However, the rational partisan model cannot account for the patterns in interest rates we have described above. We then consider the argument that the Fed responds not to the party of the sitting president, but the party of the president that first appointed the sitting chairman of the Fed. We find no evidence to support the idea that monetary policy is driven by the party of the president that first appointed the sitting Fed chairman.

The Rational Partisan Cycle Alesina and Rosenthal posit that there should be partisan differences in policy and outcomes due to uncertainty about who will be elected president. Democrats are known to favor growth over price stability and Republicans vice versa. Consequently, in the period before elections, asset holders write wage contracts that account for partisan differences in expected inflation and the possibility that there may be a change in government. For example, if expected inflation under Democrats is four and under Republicans it is two and both parties are equally likely to win the election, then expected inflation written into wage contracts in the period just before the election is three. If a Democrat (Republican) is elected, then realized inflation will exceed expected inflation and there will be a burst (decline) in output bringing it above its natural rate. In contrast, wage contracts written after the election 
will reflect the knowledge of which party was elected and, so, inflation will equal expected inflation in the later part of administrations of both parties. Economic expansions (contractions) are expected early in Democratic (Republican) terms, but growth rates should converge to the natural rate in the later part of both Democratic and Republican presidencies.

Alesina and Rosenthal find evidence for their argument in the fact that "[E]very Republican administration since the Second World War, until the second Reagan administration, had a recession that began within the first year of the term. On the contrary, none of the Democratic administrations had a recession or even a downturn in their first halves." (p. 180) They point out that these findings are in tension with the expectations of the traditional business cycle "which predicts that every administration...should begin with a recession and end with above-average growth." (p. 180). However, it is consistent with our claim that the Fed adopts an accommodative posture toward politicians who are trying to manipulate the economy for electoral purposes if and only if the White House is controlled by a Republican. Thus, the partisan nature of fluctuations in output are consistent with both the Rational Partisan model and our model. However, our model yields predictions that are distinct from the Rational Partisan model with respect to the manipulation of monetary policy.

If economic contractions occur early in Republican terms because Republican policies under shoot inflationary expectations caused by the possibility of a Democratic being elected, we would expect a technocratic Fed to lower interest rates early in Republican administrations and raise them as inflationary expectations are reflected in postelection wage contracts. Similarly, if economic expansions occur early in Democratic terms because Democratic policies exceed the inflationary expectations caused by the possibility of a Republican being elected, we would expect a technocratic Fed to raise interest rates early in Democratic terms and adjust them downward as inflationary expectations adjust. The findings we presented above suggest exactly the opposite occurs: The Fed raises (lower) interest rates early in Republican (Democratic) administrations and lower (raises) them over the next 4 years as elections approach.

The Party of the Appointing President We have argued that the Federal Reserve has preferences that lead it to act differently under Republican than Democratic presidents. Further, we have argued that this difference in behavior is aimed at electing and reelecting Republican presidents and that this occurs because of, not in spite of, the Fed's political independence. An alternative hypothesis is that the Fed is actually not all that independent - rather, the Fed may act in ways that benefit the party that first appointed its chairman (Abrams and Iossifov, 2006). Table 4 can be used to evaluate this hypothesis. In Table 4, we replicate the models from Table 1 but replace the party of the president variable with a dummy variable that equals one when the Fed chairman was initially appointed by a president of the same party as the incumbent president. If a match between the party of the president and the party that appointed the Fed Chairmen is what generates electoral monetary cycles, we would expect the coefficient on the election variable to be indistinguishable from zero, and the coefficient on the interaction term to be negative and large.

The former is true, but the latter is not - the coefficient on the interaction term is not statistically distinguishable from zero and becomes positive once we control for 
Table 4. Relationship between Election Cycles and the Federal Funds Rate (FFR), Conditional on the Match between the Party Which Appointed the Fed Chairman and the Party of the Sitting President. Ordinary Least Squares Regression with FFR as Dependent Variable. Presidential Dummies Omitted

\begin{tabular}{|c|c|c|c|c|}
\hline & Model 1 & Model 2 & Model 3 & Model 4 \\
\hline Election & $\begin{array}{l}-0.004 \\
(0.021)\end{array}$ & $\begin{array}{l}-0.001 \\
(0.020)\end{array}$ & $\begin{array}{l}-0.019 \\
(0.020)\end{array}$ & $\begin{array}{r}-0.016 \\
(0.021)\end{array}$ \\
\hline Chairman party & $\begin{array}{l}0.435 \\
(0.362)\end{array}$ & $\begin{array}{l}0.346 \\
(0.334)\end{array}$ & $\begin{array}{l}0.037 \\
(0.282)\end{array}$ & $\begin{array}{c}0.124 \\
(0.316)\end{array}$ \\
\hline Election $\times$ chairman party & $\begin{array}{l}-0.023 \\
(0.031)\end{array}$ & $\begin{array}{l}-0.029 \\
(0.029)\end{array}$ & $\begin{array}{l}0.018 \\
(0.025)\end{array}$ & $\begin{array}{c}0.008 \\
(0.029)\end{array}$ \\
\hline$\pi$ & & $\begin{array}{l}0.163^{* * *} \\
(0.040)\end{array}$ & $\begin{array}{l}0.111^{\text {** }} \\
(0.037)\end{array}$ & $\begin{array}{c}0.115^{* *} \\
(0.037)\end{array}$ \\
\hline Y-gap & & & $\begin{array}{l}0.234^{* * *} \\
(0.048)\end{array}$ & $\begin{array}{l}0.239^{\text {**** }} \\
(0.048)\end{array}$ \\
\hline Surplus/GDP & & & & $\begin{array}{c}-0.065 \\
(0.059)\end{array}$ \\
\hline $\mathrm{FFR}_{t-1}$ & $\begin{array}{l}0.873^{* * *} \\
(0.058)\end{array}$ & $\begin{array}{l}0.773^{* * *} \\
(0.062)\end{array}$ & $\begin{array}{l}0.772^{* * *} \\
(0.054)\end{array}$ & $\begin{array}{l}0.790^{* * *} \\
(0.059)\end{array}$ \\
\hline$N$ & 217 & 217 & 217 & 217 \\
\hline$R^{2}$ & 0.930 & 0.936 & 0.948 & 0.948 \\
\hline Adj. $R^{2}$ & 0.924 & 0.931 & 0.943 & 0.943 \\
\hline Resid. sd & 0.912 & 0.871 & 0.792 & 0.792 \\
\hline
\end{tabular}

Ordinary least squares regression with FFR as dependent variable. Administration dummies omitted. Robust standard errors in parentheses.

${ }^{\dagger} p<.10 ;{ }^{*} p<.05 ;{ }^{* *} p<.01 ;{ }^{* * *} p<.001$.

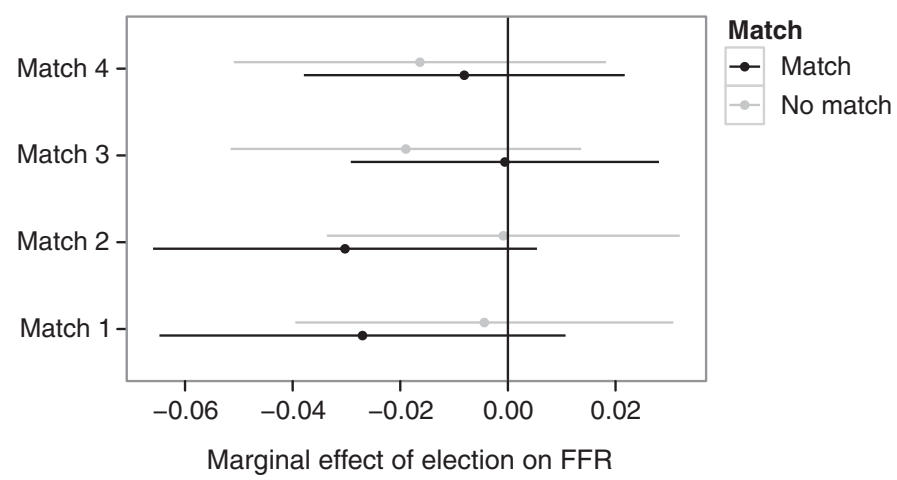

Figure 8. Marginal effect associated with moving one quarter closer when party of incumbent president matches or does not match party of president that appointed chairman. Lines indicate $90 \%$ confidence intervals.

fiscal policy. This result does not eliminate the possible existence of a preelectoral monetary expansion when the party of the incumbent president matches the party of the president that initially appointed the sitting Fed Chairman. To see if this is the case we need to sum the coefficient on the electoral variable with the coefficient on the interaction term. Figure 8 is a graphical depiction of the estimated effect of a one quarter increase in electoral proximity both when the party of the incumbent president 
does and does not match the party of the president that initially appointed the sitting Fed chairman. Note that while the estimated effect is always negative, it is never statistically significant. In summary, we find no support for the idea that the Fed accommodates electoral pressures if the incumbent president is from the same party as the president that initially appointed the Fed chairman.

It should be noted that these results are in conflict with those in Abrams and Iossifov (2006). The model we use to test their argument differs from theirs in a number of ways. We use a linear counter variable to capture electoral proximity rather than a dummy variable that equals one in the seven quarters before an election. They use a term that is the product of a dummy variable which equals one when there is a match between the party of the incumbent president and the party of the president that initially appointed the sitting Fed Chairman, but not the constitutive terms of this interaction. We believe a model that includes the constitutive terms is a better model because it allows one to compare electoral periods where there is a match with electoral periods where there is not a match. The model that does not include constitutive terms assumes what the authors say they want to test - that is, that interest rate policy is the same during nonelectoral periods as it is during electoral periods without a match. In addition, our model does not include an AR(1) term. Finally, our test includes a longer time period (July 1954 to October 2008 as opposed to 1957-2004). The null result we present here, however, stands up to the relaxation of all of these decisions (we refer interested readers to the online appendix).

\subsection{Summary}

We presented results from a set of simple ordinary least squares regressions using data on more than five decades of Fed activity. We find that the Fed:

1. Increases interest rates before elections when Democrats are in office.

2. Lowers interest rates when Republicans are vying for reelection.

3. Reacts to inflationary pressures when Democrats are in office, especially when elections are near.

4. Does not react to inflationary pressures when Republicans are facing reelection.

5. Is insensitive to the output gap when Democratic presidents are standing for reelection.

6. Is more sensitive to the difference between realized and potential GDP at the end of a Republican's term.

Unlike competing models, our argument predicts all of these results. What distinguishes our argument from alternative models is the idea that the Fed is cognizant of the intertemporal tradeoff it faces when Republicans control the White House. Models that do not account for this intertemporal tradeoff produce predictions in conflict with our findings.

To see why, recall that extant explanations of the politics of macroeconomic policy vary based on the assumptions they make about effectiveness of central bank independence and whether elected officials are partisan or electoralist.

For example, if the Fed were independent and indifferent and both parties were opportunistic vote maximizers, we would find evidence of the Fed counteracting electoralist behavior of incumbents from both parties. Thus, we would expect to 
observe findings (1), (3), and (5) but not (2), (4), and (6). If, on the contrary, the Fed was simply bending to the will of opportunistic leaders in both parties, we would expect to observe (2), (4), and (6), but not (1), (3), and (5).

Alternatively, if the Fed were independent and indifferent in a world where the partisan model operated, we would not see a connection between the Fed's reaction function and the electoral calendar. Thus, we would have no reason to expect to observe either (2), (4), or (6). If this last world pertained and the Fed knew something about the inflationary tendencies of the Democrats compared with the Republicans that was not captured in the measures of expected inflation, then we might observe tighter monetary policies under the Democrats, but this would not be tied to the electoral calendar. Thus, we again might observe (1), (3), and (5) but not (2), (4), and (6) - and certainly not (4) and (6) together. That is, it is possible that the Fed charges Democrats an interest rate premium because it believes measures of expected inflation do not fully capture the policy differences between the parties. If this were true the Fed would always react to changes in both inflation and the output gap but the magnitude (but not significance) of the coefficients would depend on the party that controls the White House. In other words, the lines in the marginal effects graphs would not cross, and the red lines capturing the reaction function for Republicans would be parallel to the x-axis.

If the parties acted according to the partisan logic and the Fed were dependent, none of our six findings should be true. In this world, we would expect the Fed to reduce interest rates before elections under Democrats, but not under Republicans, because the latter hold strong antiinflationary preferences. Likewise, we would expect the Fed to react to the output gap before elections under Democrats, but not under Republicans.

\section{CONCLUSION: DOES THE FED TIP THE SCALE?}

The Fed has macroeconomic policy preferences that are closer to the median of the Republican party than to the median of the Democratic party. A partially independent central bank will, all else equal, set policies that are a weighted average of the party in power and its own preferences. Consequently, in normal times, the Fed expects it to be easier to accomplish its policy goals when Republicans control the White House than when Democrats do. As voters reward preelectoral expansions in output, strategic central bankers face an intertemporal tradeoff when Republicans are in power. Do they stick to their antiinflationary "guns" or do they compromise in the short-run to increase the probability that policy goals in the future will be easier to accomplish? When Democrats are in the White House the Fed faces no such tradeoff. Acting as a good inflation hawk now has the added benefit of increasing the likelihood that they will have a party in power in the future that requires less accommodation.

The choice confronting partially independent strategic central bankers when faced with a Republican incumbent is simple: compromise now, or compromise later. Our results suggest that since achieving operational independence in the middle of the last century, the Fed has consistently chosen the former. The behavior we have observed is consistent with the possibility that the Fed seeks to aid the election and reelection of Republican presidents.

We have not examined whether the Fed's politically motivated changes in interest rates has had the intended effects on macroeconomic aggregates in part because the link between interest rates and growth is a long standing question in macroeconomics 
that we do not believe we can adjudicate here. We also have not examined whether the difference in the Fed's reaction function under Democrats and Republicans has had an electoral impact. However, a glimpse at the last century of American history is suggestive. In the half century since the "Treasury-Fed Accord" gave to the Fed operational independence by removing its obligation to monetize the Treasury's debt at a fixed rate, the White House has been occupied by a Republican for almost two-thirds of the time. Every Republican president to run for reelection since the Fed became operationally independent - with the exception of George Herbert Walker Bush - was reelected. In contrast, Clinton was the only Democratic president to serve two full terms after the Fed became independent. ${ }^{8}$; Democrats held the presidency slightly more than half of the portion of the twentieth century that preceded the Treasury-Fed Accord. Although not a single Republican president was reelected in the first half of the twentieth century (though Republican presidents frequently succeed each other), both Democratic presidents in the first half of the twentieth century were re-elected: Wilson once, and Roosevelt three times.

Our findings also have implications for the broader literature on comparative political economy in industrial democracies - particularly as they relate to the partisan model of macroeconomic policy that launched the field of Comparative Political Economy more than three decades ago (Cameron, 1978; Hibbs, 1977; Tufte, 1978). While intuitive, there is little evidence to support the partisan model and what little evidence can be found for partisan difference in broad measures of monetary and fiscal policy or outcomes is as likely as not to support a counterintuitive "Nixon in China" type of relationship where left-wing parties preside over higher interest rates and smaller deficits than left-wing governments. Casual empiricists have been unable to avoid the glaring presence of record deficits during the Reagan and Bush presidencies. And one recent study (Broz, Forthcoming) finds that right-wing governments are associated with the "twin deficits" thought to be a harbinger of financial crises Reinhart and Rogoff (2009).

What explains the dearth of evidence of traditional partisan cycles? What might explain the occasional finding that right-wing governments are more profligate than left? The evidence presented in this article suggests the answer lies in two places. First, we believe that while there may be partisan differences in underlying preferences, the vagaries of democratic political competition induce in leaders of all stripes to act in similar fashion. And that fashion is to respond to the tendency of voters to assess economic performance in the recent past when deciding whether or not to support the incumbent. This induces all incumbents to act as if they prefer macroeconomic expansions in preelectoral periods (and, perhaps, macroeconomic contractions in postelectoral periods). Second, we argue that independent central banks run by conservative central bankers are likely to be more eager to thwart the electorally motivated expansions by left-wing governments than right-wing governments. Consequently, the lack of widespread support for the traditional partisan hypothesis is the result of the fact that all parties would like to act like right-wing governments after elections and left-wing governments before elections. In the absence of central bank independence, there is nothing to stop governments of all ideological stripes from doing so, and so, we observe no difference between the parties. In the presence of central bank independence, left-wing governments are constrained and/or deterred from attempting to cre-

\footnotetext{
${ }^{8}$ While Johnson was also elected to a second term in 1964 while an incumbent, he had assumed office after Kennedy's assassination in 1963. In March, 1968, he announced that he would not seek reelection.”
} 
ate preelectoral macroeconomic expansions, but right-wing governments are not. And so, under these conditions, we observe the counterintuitive partisan difference that right-wing governments preside over more lax fiscal and monetary policies than leftwing governments. This would also help explain why Broz finds a link between rightwing governments and both fiscal and current account deficits and the financial crises they portend.

\section{ACKNOWLEDGEMENTS}

The authors thank participants of the following seminars for their helpful comments and suggestions: the Boston College International Economic Policy and Political Economy Seminar; the Harvard University Faculty Discussion Group on Political Economy; the Johns Hopkins Bologna Institute for Policy Research Seminar; the Electoral Politics Speaker Series at Hebrew University of Jerusalem; the Political Economy of Reforms Seminar at the University of Mannheim; the Comparative Political Economy Seminar at Nuffield and Merton Colleges, Oxford; the Center for Political Studies Interdisciplinary Workshop on Politics and Policy, and the AAAPSA meetings at the University of Michigan. We also thank, specifically, Michael Bailey, Lawrence Broz, Rob Franzese, Jeff Frieden, Fabio Ghironi, Orit Kedar, Desmond King, Robert Mickey, Rob Salmond, David Singer, Michael Shalev, David Soskice, and the Editor and anonymous reviewers at Economics \& Politics for comments, suggestions, and encouragement.

WILLIAM ROBERTS CLARK

VINCENT AREL-BUNDOCK

University of Michigan

University of Michigan

\section{REFERENCES}

Abrams, B. A. and P. Iossifov, 2006, Does the Fed contribute to a political business cycle? Public Choice 129, 249-262.

Adolph, C., 2004, Succession in the temple: central banker careers and the politics of appointment. Technical report Working Paper, University of Washington.

Alesina, A. and H. Rosenthal, 1995, Partisan Politics, Divided Government, and the Economy. (Cambridge University Press, New York).

Alpanda, S. and A. Honig, 2009, The impact of central bank independence on political monetary cycles in advanced and developing nations. Journal of Money, Credit and Banking 41, $1365-1389$.

Barro, R. J. and D. B. Gordon, 1983, A positive theory of monetary policy in a natural rate model. The Journal of Political Economy 91, 589-610.

Bartels, L. M., 2010, Unequal Democracy: The Political Economy of the New Gilded Age. (Princeton Univ Press, Princeton, NJ).

Berger, H. and F. Schneider, 2000, The bundesbank's reaction to policy conflicts. in: J. de Haan, ed., The History of the Bundesbank: Lessons for the European Central Bank, Routledge, London, pp. 43-66.

Broz, J. L., Forthcoming, Partisan financial cycles, in: D. L. Lake and M. Kahler, eds., Politics in the New Hard Times: The Great Recession in Comparative Perspective (Cornell University Press, Ithaca, NY.

Cameron, D. R., 1978, The expansion of the public economy: a comparative analysis. American Political Science Review 72, 1243-1261.

Clark, W. R. and M. Hallerberg, 2000, Mobile capital, domestic institutions, and electorally induced monetary and fiscal policy. The American Political Science Review 94, 323-346. 
Cusack, T. R., 2001, Partisanship in the setting and coordination of fiscal and monetary policies. European Journal of Political Research 40, 93-115.

Franzese, R. J., 1999, Partially independent central banks, politically responsive governments, and inflation. American Journal of Political Science 43, 681-706.

Galbraith, J., O. Giovannoni, and A. J. Russo, 2007. The Fed?s real reaction function: monetary policy, inflation, unemployment, inequality? and presidential politics. University of Texas International Politics No. 42.

Hibbs Jr.D. A., 1977, Political parties and macroeconomic policy. The American Political Science Review 71, pp. 1467-1487.

Hyndman, R. J. and Y. Khandakar, 2008, Automatic time series forecasting: the forecast package for R automatic time series forecasting: the forecast package for R. Journal of Statistical Software 27.

Keefer, P. and D. Stasavage, 2003, The limits of delegation: veto players, central bank independence, and the credibility of monetary policy. American Political Science Review 97, 407-423.

Kydland, F. E. and E. C. Prescott, 1977, Rules rather than discretion: the inconsistency of optimal plans. The Journal of Political Economy 85, 473-491.

Lohmann, S., 2003, Rationalizing the political business cycle: a workhorse model. Economics \& Politics 10, 1-17.

McCubbins, M. D. and T. Schwartz, 1984, Congressional oversight overlooked: police patrols versus fire alarms. American Journal of Political Science 28, 165-179.

Posen, A. S., 1995, Declarations are not enough: financial sector sources of central bank independence. NBER Macroeconomics Annual 10, 253-274.

Reinhart, C. M. and K. S. Rogoff, 2009, This Time is Different: Eight Centuries of Financial Folly. (Princeton University Press, Princeton, NJ).

Rogoff, K., 1985, The optimal degree of commitment to an intermediate monetary target. The Quarterly Journal of Economics 100, 1169.

Tufte, E. R.. 1978, Political Control of the Economy. (Princeton University Press, Princeton, NJ).

Walsh, C. E., 1995, Optimal contracts for central bankers. The American Economic Review 85, $150-167$.

\section{SUPPORTING INFORMATION}

Additional Supporting Information may be found in the online version of this article:

Appendix S1. Base and taylor models, excluding the volcker chairmanship.

Appendix S2. Base and taylor models, excluding the volcker chairmanship and the last two quarters of each election cycle.

Appendix S3. Base and taylor models with chairmen dummy variables.

Appendix S4. Base and taylor models, including the obama presidency.

Appendix S5. Forward-looking taylor models with alternative measures of inflationary expectations.

Appendix S6. Inflationary surprise taylor models with alternative measures of inflationary expectations.

Appendix S7. Base and taylor models with four lagged dv. base models with arima.

Appendix S8. Base and taylor models, using federal government expenditures as fiscal control.

Appendix S9. Base and taylor models, excluding the last quarter before each election. Appendix S10. Base and taylor models, excluding the last two quarters before each election.

Appendix S11. Base and taylor models, controlling for the party which first appointed the sitting fed chairman.

Appendix S12. Base model, estimated in subsamples of fed chairman appointed by either democratic or republican presidents.

Appendix S13. Alternative explanation. 